\title{
GROUNDWATER VULNERABILITY OF THE KARST - FISSURE HYDROGEOLOGICAL STRUCTURE OF SOUTH - FACING SLOPES OF THE NÍZKE TATRY MTS., SLOVAKIA
}

\author{
RANLJIVOST PODZEMNE VODE V KRAŠKO-RAZPOKLINSKI \\ STRUKTURI JUŽNIH POBOČIJ NIZKIH TATER, SLOVAŠKA
}

\author{
Erika KOVÁČOVÁ ${ }^{1} \&$ Peter MALÍK²
}

\begin{abstract}
UDC 556.3:551.44 (437.6)

Erika Kováčová \& Peter Malik: Groundwater vulnerability of the karst - fissure hydrogeological structure of south - facing slopes of the Nizke Tatry mts., Slovakia

An "intrinsic vulnerability" (according to Zwahlen et al., 2004) to any contamination in general is considered using Malík's extension (2005) of the Kullman's method (2000), based on the assessment of the degree the rock disruption and karstification, affecting the shape of spring discharge recession curves. It is based on the presumption that the intensity of natural contamination attenuation processes depends on rock disruption/ karstification. The method is applied on the Mesozoic rock environment of the most important hydrogeological structure in the southern slopes of the Nízke Tatry Mountains. Hydrograph analyses of groundwater depletion in the gauged or exploited springs were used for assessment of groundwater vulnerability to human and/or natural pollution. Differences in character of individual depletion hydrographs enable assessment an extent of absorption and elimination processes during the groundwater penetration through the rock environment from the infiltration area to the outflow in the spring or exploited source. The depletion hydrographs reflect not only the character (effect) of outflow area but reflect the effects whole infiltration and accumulation area. In total, 68 individual recession curves from 9 gauged springs were analysed. Obtained degrees of groundwater vulnerability are evaluated by 10 degree range of the Kullman's vulnerability scheme, adjusted by Malík. The reached vulnerability values are consequently applied and assigned to the lithological types of discharge area of gauged springs. This study also describes an existence of individual laminar and turbulent sub-regimes that occur in the karts-fissure rock environment, the type of rock disruption from open micro- to macro fissures - to karst channels and subsequent estimation of the karstification degree.
\end{abstract}

Key words: groundwater vulnerability, sensitivity to pollution, hydrograph analyses, karstification degree, recession curves, Nízke Tatry Mts., Slovakia.
Izvleček

UDK 556.3:551.44 (437.6)

Erika Kováčová \& Peter Malík: Ranljivost podzemne vode v kraško-razpoklinski strukturi južnih pobočij Nizkih Tater, Slovaška

$\mathrm{V}$ članku obravnavamo ranljivost vodonosnika (v smislu Zwahlen et al., 2004) na kakršnokoli onesnaženje $\mathrm{z}$ uporabo Malikove (2005) razširitve Kullmanove (2000) metode. Slednja temelji na obravnavi vpliva stopnje razpokanosti in zakraselosti kamnine na recesijo pretočnega hidrograma kraških izvirov. Metoda temelji na domnevi, da je naravno dušenje intenzitete onesnaženja odvisno od stopnje zakraselosti oz. razpokanosti kamnine. Metodo smo uporabili na območju sestavljenem iz kamnin mezocojskih starosti v najbolj pomembni hidrogeološki strukturi južnih pobočij Nizkih Tater. Na osnovi analiz recesijskih krivulj izvirov, ki jih izkoriščajo oz. jim merijo pretok, smo sklepali o stopnji absorbcije in drugih procesov izločitve onesnaževal med podzemnim pretakanjem vode. Recesijske krivulje ne odražajo le območje iztoka, pač pa celoten sistem pretakanja, vključno z infiltracijo in akumulacijo. Skupaj smo analizirali 68 recesijskih krivulj z 9 izvirov. Dobljene stopnje ranljivosti smo ovrednotili po 10 stopenjski lestvici in vrednosti uporabili na obravnavanih območjih glede na litologijo zaledja spremljanih izvirov. V študiji obravnavamo tudi območja laminarnih in turbulentnih tokov, ki se pojavijo v kraško razpoklinskem vodonosniku in tipe nezveznosti $\mathrm{v}$ kamninah, od mikro do makro razpok in kraških kanalov.

Ključne besede: ranljivost podzemne vode, občutljivost na onesnaženje, analiza hidrografa, stopnja zakraselosti, receijska krivulja, Nizke Tatre, Slovaška

\footnotetext{
${ }^{1}$ State Geological Institute of Dionyz Stur, Mlynská dolina 1 Bratislava, Slovakia; e-mail: kovacova@geology.sk

${ }^{2}$ State Geological Institute of Dionyz Stur, Mlynská dolina 1, Bratislava, Slovakia; e-mail: malik@geology.sk

Received/Prejeto: 18.09.2006
} 


\section{INTRODUCTION}

The concept of groundwater vulnerability is based on the assumption that the physical environment may provide some degree of protection to groundwater again anthropogenic and/or natural impacts, and that degree of vulnerability is a function of the hydrogeologic setting and prevailing patterns of pollution (Vrba \& Zaporozec, 1994; Ibe et al., 2001). Vulnerability is regarded as an intrinsic property of a groundwater system that depends on the sensitivity of that own system to human and/or natural impacts.

Two types of vulnerability of groundwater were recognized by Daly et al. (2002): intrinsic and specific vulnerability. Definitions of these types of groundwater vulnerability were established in the framework of multilateral project of European hydrogeologists - „COST Action 620 - Vulnerability and risk mapping for the protection of carbonate aquifers“. Not only these definitions, but also common understanding of the groundwater vulnerability factors were recognized within this project (Zwahlen et al., 2004), and a set of methodical steps - a „European approach" of groundwater vulnerability assessment. Although primarily addressed to the karst rock media, this approach can be applied to all kinds of rock environments as it only extends assessments of some special features of karst environments (groundwater flow concentration) if exists (Malík \& Švasta, 2004).

An "intrinsic vulnerability", evaluating a geological, hydrological and hydrogeological characteristics of site and does not depend on patterns of pollution.

A "specific vulnerability" is defined as a vulnerability of groundwater against specific contaminant or several contaminants caused by human activity.

The output of Kullman's method (2000) using hydrograph analysis of groundwater depletion of the gauged springs can be marked as an „intrinsic vulnerability" as it does not recognize the specific properties of individual types of contaminants (heavy metals, pesticides, nitrates ...). However, as it does not correspond in all aspects with the "standard European" definitions and approaches (Daly et al., 2002, Zwahlen et al., 2004), some authors (Malík, 2005) prefer to name this output as "groundwater sensitivity to pollution" to make clear difference between both concepts. The target Kullman's method application in this case was the groundwater in the karst-fissure hydrogeological structure of the Nízke Tatry Mountains, Slovakia, located between the municipalities of Podbrezová, Krpáčovo, Jasenie and Lopej.

\section{CHARACTERISTIC OF HYDROGEOLOGICAL STRUCTURE BETWEEN PODBREZOVÁ, KRPÁČOVO, JASENIE AND LOPEJ}

The Nízke Tatry Mountains as the western part of the Carpathian arch are located in the north of Slovakia. The highest peak is Dumbier with an elevation of 2,043 metres a. s. 1. By geological structure, the Nízke Tatry Mts. belong to the "core-type" of mountain ridges, with a crystalline "core" and "envelope" built by autochthonous Mesozoic sediments plus several overthrusted units built also by Mesozoic sediments. The Mesozoic carbonate rocks, mostly various types of limestones and dolomites, are of Middle and Upper Triassic age. They represent one of the most important karst water resources areas in Slovakia.

Hydrogeological structure of the southern slopes of the Nízke Tatry Mountains between Podbrezová, Krpáčovo, Jasenie and Lopej $\left(37.74 \mathrm{~km}^{2}\right.$ - Fig.1) is the most important natural groundwater reservoir with high quality drinking water, bound also to Triassic - Mesozoic rock environment. This highly permeable structure is about 1,200 metres thick. Considering the main geological units, the carbonate rocks in the structure belong to Hronikum unit with middle Choč nappe at the bottom, overlayed by two independent segments of upper Choč nappe. All these partial nappes are from the bottom to top built by the same lithology: Lower Triassic seiss and kampil layers (sandy shales and sandstones), Middle Triassic Gutenstein limestones, "Choč dolomites", reifling limestones, lunz layers (claystones and sandstones), Upper Triassic "main dolomites" - hauptdolomites, and dachstein limestones. All these layers have their equivalents in Ober Ost Alpine units in Austrian Alps. Under the Choč nappe, the Veporikum unit is placed as an underlying sequence of Mesozoic isolators and aquifers.

The hydrogeological structure itself has a very complicated hydraulic and hydrogeochemical system of groundwater flow, due to the several open fault systems. Complex tectonic settings of the area enabled a creation of three main hydraulic systems of groundwater flow (Fig.2), which were defined by Kullman (1983, 1990):

1. dynamic system of groundwater flow connected with the Hronský fault, a boundary fault of uplift of the Nízke Tatry Mts., 


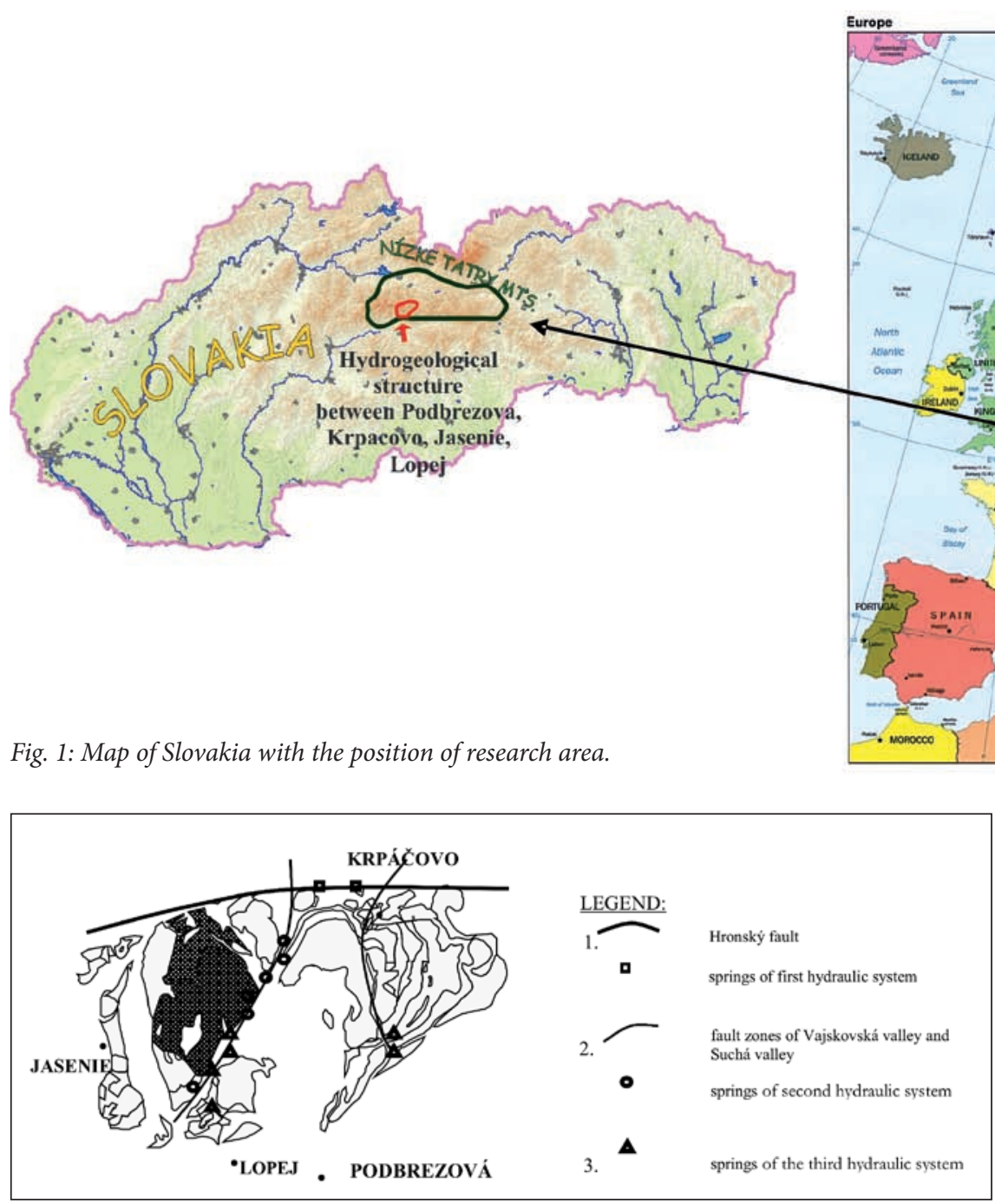

Fig. 2: Hydrogeological structure between Podbrezová, Krpáčovo, Jasenie and Lopej and three different hydraulic systems of groundwater flow.

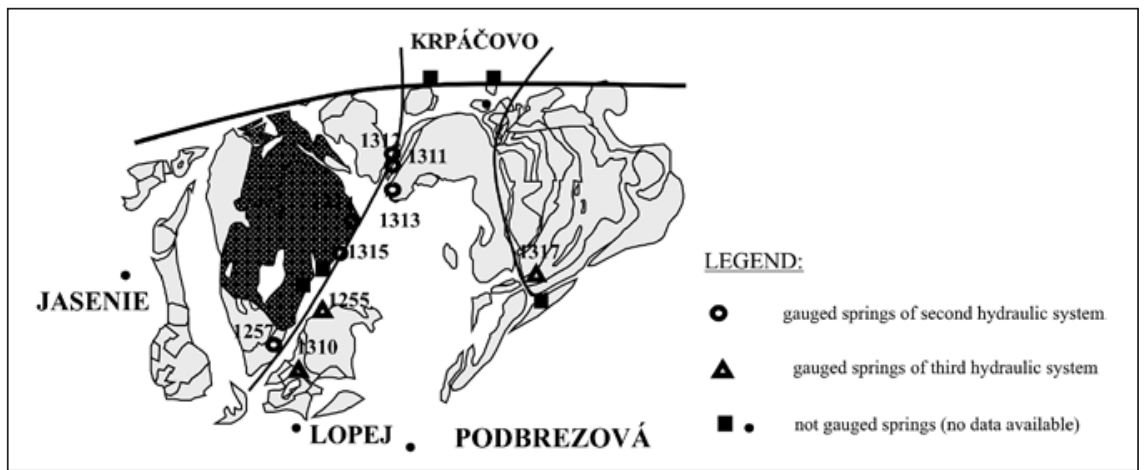

Fig. 3: Gauged springs of hydrogeological structure between Podbrezová, Krpáčovo, Jasenie and Lopej.

2. dynamic system of groundwater flow connected to transverse open fault zones cutting the structure along the Vajskovská and Suchá valleys - causing the circula- tion of the biggest groundwater amount, with quick and shallow movement,

3. inner system inside the hydrogeological structure itself - slower groundwater movement through the less disrupted parts of the hydrogeological structure.

The first hydraulic system - groundwater circulation controlled by the Hronský zlom fault is drained by 2 springs, in Krpáčovo and Tále area. In spite of its importance, this open fault hydraulic system could not be evaluated because of missing data of discharge time series. The second hydraulic system - transverse open fault zones passing Vajskovská valley and Suchá valley, is drained by 6 springs: Spring of king Matthias (No. 1257) in Lopej, Uhlište (No. 1311), Vrabec (No. 1312), Horný 1, 2, 3 (No. 1313), Horný 4 (No. 1314) a Dolný (No. 1315) in Dolná Lehota. The third hydraulic system (groundwater movement within hydrogeological structure) is drained by 6 springs, from which 3 data available (gauged) springs are Hámor (No. 1255), Za 
továrňou (No. 1310) in Dolná Lehota and Starý mlyn (No. 1317) in Horná Lehota (Fig.3).

Estimated specific groundwater runoff of whole hydrogeological structure is ranging from 8.5 to $9.51 . \mathrm{s}^{-1} \cdot \mathrm{km}^{-2}$ and the total sum of dynamic natural groundwater re- sources originating in the structure is $320-3591 . \mathrm{s}^{-1}$ (Kullman, 1983, 1990). Prognostic groundwater reserves (counting also external groundwater outputs) are estimated as $4681 . \mathrm{s}^{-1}$ (Hanzel et al., 1990).

\section{METHODS}

The applied Kullman's method $(1997,2000)$ adjusted by Malík (2005) is based on the assessment of the degree of groundwater vulnerability resulting from the rock disruption and karstification. Proposed vulnerability classification has 10 degrees of vulnerabilities assigned by differences in character of karstification and rock disruption signalized by individual depletion hydrographs. Differences in character of individual depletion hydrographs enable assessment of the anticipated possibility of reduction, absorption or elimination processes during the groundwater penetration through the rock environment.

Degree of vulnerability equal to 1 represent low vulnerability and only one laminar groundwater flow is present here. The risk of groundwater contamination is very low. The highest vulnerability equal to $10^{\text {th }}$ degree represents groundwater circulation exclusively in open karst channels, where only turbulent sub-regimes are present, without a mark of single laminar one. The risk of extensive groundwater contamination is very high. The highest vulnerability is then connected to developed karstification in large areas, with wide opened channels, swallow holes or sinkholes. Besides vulnerability, several other characteristics of rock environment, mainly the aperture of joints present, are influencing the final shape of recession curves: the existence of laminar or turbulent sub-regimes points out on the ratio of microfissures, macrofissures and open karst channels.

Discharge time series were analyzed for their decreasing parts, exceeding suggested threshold value of at least 8 weeks of uninterrupted decrease. From these, recessions possibly influenced by sudden precipitation events were excluded, as in spite of their decreasing character there is a danger of lowering the "decrease angle" on the hydrograph. Finally, a master recession curve was created by "best fit" simulation of the curve using the different starting discharge points of each subregime and 3 possible $\alpha$ depletion coefficients and 3 possible $\beta$ depletion coefficients.

The method was applied on the Mesozoic rock environment - Triasic carbonates of Hronicum unit. In total, 68 recession curves from 9 gauged springs were analyzed. Final groundwater vulnerability degree of individual springs was based on the classification of the mean values of recession curve's parameters - depletion coefficients $\alpha$ and $\beta$ (Malík, 2005). Depletion coefficients also suggest on the type of groundwater flow regime. Coefficient a suggest a laminar regime of groundwater flow and coefficient $\beta$ suggest a turbulent regime of groundwater flow. Each spring was characterised by its individual depletion coefficients and subsequent vulnerability (sensitivity to pollution) degree (Malík, 2005). The reached median value of the vulnerability degree was consequently applied also to different lithological types present in the discharge area of gauged springs. In this way, groundwater vulnerability of individual lithological types was defined. The outcome is the groundwater vulnerability map of studied hydrogeological structure. The same was done for individual hydraulic systems present in the Podbrezová - Krpáčovo - Jasenie - Lopej hydrogeological structure. Based on the recession characteristics of the springs bound to different hydraulic systems, mean groundwater vulnerability (sensitivity to pollution) degree of each hydraulic system was described.

\section{RESULTS}

GROUNDWATER VULNERABILITY AND REGIME OF GROUNDWATER FLOW OF INDIVIDUAL SPRINGS

The lowest vulnerability degree index of $\mathbf{2}$ was given to the Starý mlyn spring (No.1317) in Dolná Lehota. The analysis of depletion curves from weekly data of 30 years periods suggest an existence only one laminar regime of groundwater flow (Fig. 4). The risk of groundwater contamination is very low, is only general risk of surface entry of contamination into rock environment, with pos- 

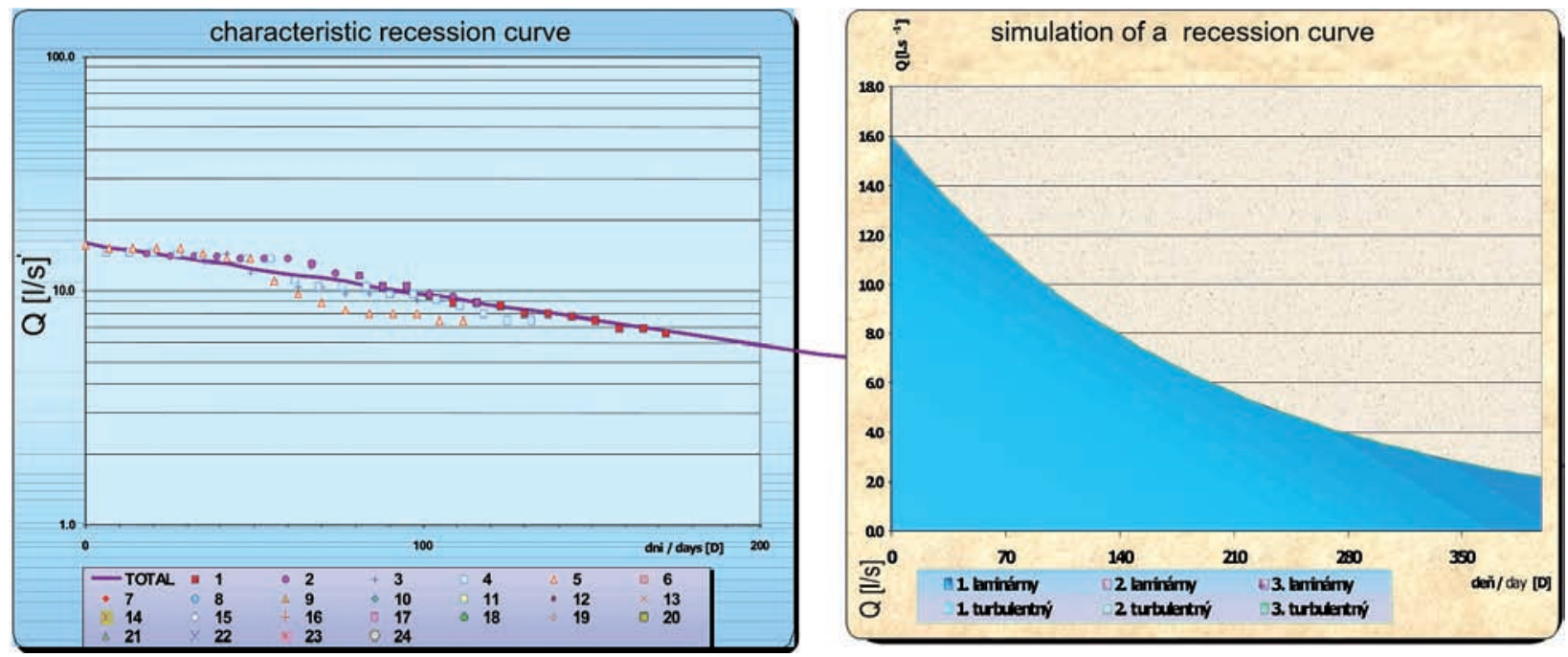

Fig. 4: Characteristic recession curve of spring No.1317 Starý mlyn in Dolná Lehota - lowest vulnerability (sensitivity to pollution) degree.

sibility of its great retention, fixation and dispersion. We can expect very low probability of significant contamination of groundwater source.

Higher vulnerability degree values $\mathbf{- 2 . 5}$ and $\mathbf{2 . 7}$ - are reached by springs Za továrňou (No. 1310) and Hámor (No. 1255) in Dolná Lehota. Two laminar regimes are present here. Very low risk of groundwater contamination is present, but possibility of surface entry of contamination with its probable retention, fixation and dispersion is high. Probability of groundwater source contamination is very small, with exception of possible entry of contamination from closer vicinity (Kullman, 2000, Malík, 2005).
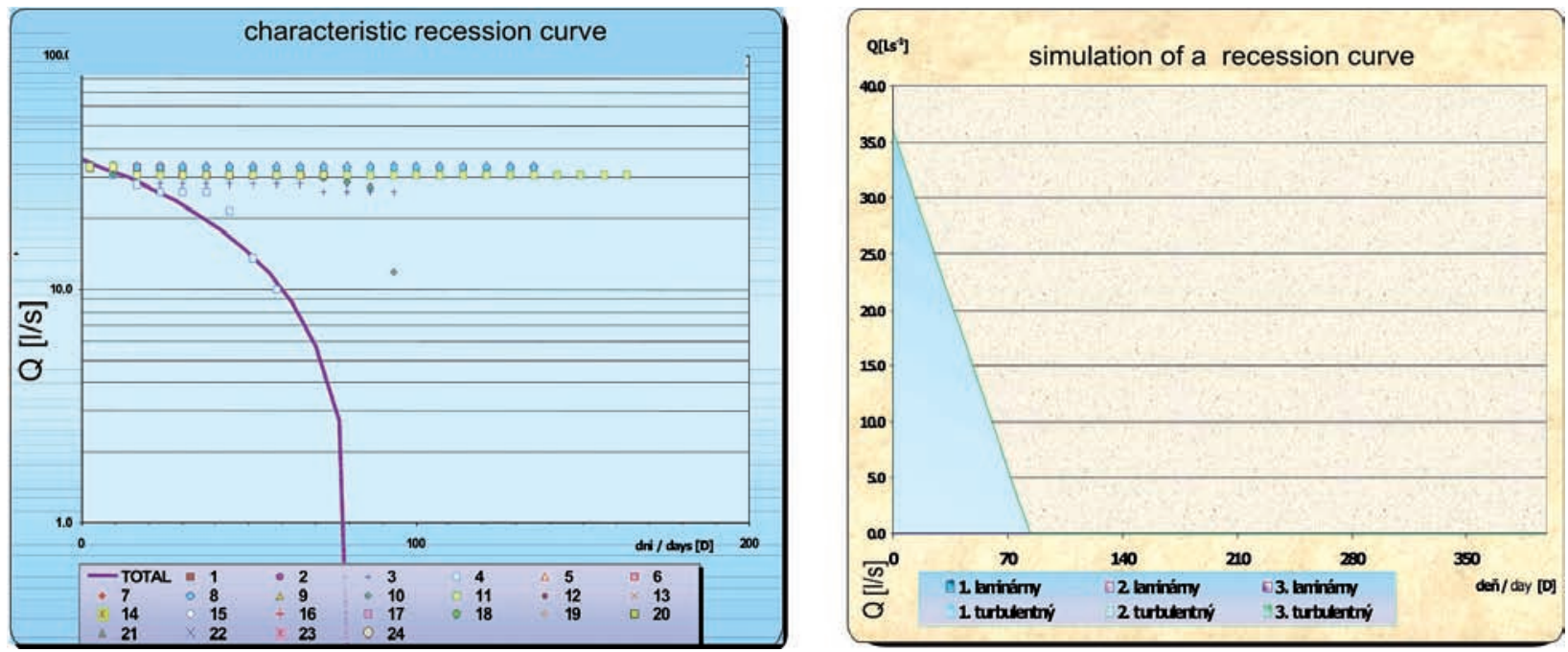

Fig. 5: Characteristic recession curve of spring No.1257 Spring of king Matthias in Dolná Lehota - highest vulnerability (sensitivity to pollution) degree. 
sion of contamination, but point contamination sources represent a real danger to groundwater (Kullman, 2000).

More vulnerable seem to be spring Uhlište (No. 1311) and Dolný (No. 1315) in Dolná Lehota with vulnerability value $\mathbf{5 . 5}$ typical for karstic areas. Regime of groundwater depletion is composed by two subregimes with laminar flow and one subregime with turbulent flow. There is a limited possibility of its retention, fixation, but mainly dilution. Arrival of contamination to groundwater sources will be rather quick, but in lower concentrations, with longer duration period.

The higher vulnerability is determined for Spring of king Matthias (No.1257) in Lopej with vulnerability value 9 and existence of one turbulent regime of groundwater flow (Fig. 5). Possibility of groundwater affection by significant contamination point source with fast transport, low retention and dispersion is high. There is very high risk of groundwater contamination from far-away contaminant source and also fast increase of contaminant in groundwater source, with high concentration, but with limited duration period.

\section{GROUNDWATER VULNERABILITY \\ OF INDIVIDUAL LITHOLOGICAL TYPES}

From existing depletion hydrographs of individual gauged springs is possible to define also a mean value of groundwater vulnerability (sensitivity to pollution) degree of individual lithological types, based on the mean characteristics of springs connected to these lithological types. There were enough data to evaluate four different lithological types - Choč dolomites, Gutenstein limestones, Hauptdolomites and carbonatic conglomerates of Vajsková. These lithological types are present in the discharge areas of gauged springs.

Choč dolomites show mostly laminar discharge sub-regimes and only sometimes turbulent sub-regime can by recognised. Substantial role in groundwater discharge has a sub-regime with laminar flow. The regime of groundwater discharge is based on differences in discharge curves and different discharge coefficient. The risk of more extensive groundwater contamination is low, with exception of close vicinity of the source. Degree of vulnerability according to Kullman's classification (2000) adjusted by Malík (2005) reaches value of 3.3.

Conglomerates of Vajsková can by characterised by the presence of two laminar sub-regimes in spring hydrographs, from time to time a turbulent sub-regime can by present. Rock environment is characterised by irregularly developed fissure network, with majority of open macro-fissures. The risk of more extensive groundwater contamination is low. Value of groundwater sensitivity to pollution (groundwater vulnerability) of this rock envi- ronment reaches $\mathbf{4 . 1}$ degree of Kullman's classification (2000) adjusted by Malík (2005).

Gutenstein limestones reach the vulnerability degree of 5. Regime of groundwater discharge is composed from sub-regime of turbulent flow and laminar flow subregime. Substantial role in groundwater discharge has a sub-regime with laminar flow. Rock environment is characterised by an existence of crushed water-bearing zones or by dense network of open small fissures in combination with simple, partly phreatic conduit system of considerable extent. The risk of groundwater contamination by surface entry into the rock is low. There is a possibility of contamination increase by significant point pollution source with direct connection of the karst system to the surface.

"Main dolomites" - "hauptdolomites" reached the highest vulnerability $\mathbf{5 . 5}$ from 10 degrees range of used classification. This fact is quite interesting from the point of view of rock composition, but it also documents, that - on the contrary to the Mediterranian dolomite sequences - the Trassic dolomites in the Carpathian arc show a karstification potential and on many places are also strongly karstified. Regime of groundwater flow of the spring Dolný in Dolná Lehota is created by a superposition of two sub-regimes with turbulent flow and one sub-regime with laminar flow. We can assume higher risk of contamination by surface entry and also higher risk coming from possible point source of contamination.

GROUNDWATER VULNERABILITY OF

DIFFERENT HYDRAULIC SYSTEMS OF THE

HYDROGEOLOGICAL STRUCTURE ON THE SOUTHERN SLOPES OF THE NÍZKE TATRY MTS. BETWEEN PODBREZOVÁ, KRPÁČOVO, JASENIE AND LOPEJ

The first hydraulic system - Hronský zlom fault could not by evaluated because of insufficient data.

The second hydraulic system - an open fault zones passing the Vajskovská valley and Suchá valley, is in average characterised by one sub-regime with turbulent flow and one sub-regime with laminar flow. Rock environment should be then characterised by an existence of crushed water-bearing zones - in this case fault zones of Vajskovská and Suchá valley. Mean degree of vulnerability reaches value of $\mathbf{5 . 2 5}$ (Tab. 1). We can assume higher risk of groundwater contamination by surface entry into the rock block and also by significant point source of contamination with direct connection of the karst system to the surface.

The third hydraulic system - inner groundwater circulation inside the hydrogeological structure itself reaches lower, 2.5 value of vulnerability degree (Tab. 2). Generally only a laminar groundwater flow is present in 


\begin{tabular}{|c|c|c|c|c|c|c|}
\hline $\begin{array}{l}\text { Number } \\
\text { (SHMI) }\end{array}$ & Name of spring & Site & Rock environment & $\begin{array}{c}\text { Groundwater } \\
\text { vulnerability } \\
\text { of gauged } \\
\text { springs }\end{array}$ & $\begin{array}{c}\text { Vulnerability } \\
\text { of litological } \\
\text { types }\end{array}$ & $\begin{array}{c}\text { Final } \\
\text { vulnerability } \\
\text { of second } \\
\text { hydraulic } \\
\text { system }\end{array}$ \\
\hline 1257 & $\begin{array}{l}\text { Kings's Matyas } \\
\text { spring }\end{array}$ & Dolná Lehota & Gutenstein limestones & 9.0 & \multirow[t]{2}{*}{5.0} & \multirow{6}{*}{5.25} \\
\hline 1311 & Uhlište & Dolná Lehota & Gutenstein limestones & 5.5 & & \\
\hline 1312 & Vrabec & Dolná Lehota & Choč dolomites & 4.3 & \multirow{2}{*}{3.3} & \\
\hline 1313 & Horný $1,2,3$ & Dolná Lehota & Choč dolomites & 4.0 & & \\
\hline 1314 & Horný 4 & Dolná Lehota & $\begin{array}{l}\text { Conglomerates of } \\
\text { Vajsková }\end{array}$ & 5.0 & 4.1 & \\
\hline 1315 & Dolný & Dolná Lehota & "Hauptdolomites" & 5.5 & 5.5 & \\
\hline
\end{tabular}

Tab. 1: Groundwater vulnerability of the second hydraulic system of fault zones of Vajskovská valley and Suchá valley.

\begin{tabular}{|l|l|l|l|c|c|c|}
\hline $\begin{array}{l}\text { Number } \\
\text { (SHMI) }\end{array}$ & Name of spring & Site & Rock environment & $\begin{array}{c}\text { Groundwater } \\
\text { vulnerability } \\
\text { of gauged } \\
\text { springs }\end{array}$ & $\begin{array}{c}\text { Vulnerability } \\
\text { of litological } \\
\text { types }\end{array}$ & $\begin{array}{c}\text { Fulnerability } \\
\text { of second } \\
\text { hydraulic } \\
\text { system }\end{array}$ \\
\hline $\mathbf{1 2 5 5}$ & Hámor & Dolná Lehota & $\begin{array}{l}\text { Conglomerates of } \\
\text { Vajsková }\end{array}$ & 2.7 & \multirow{2}{*}{4.1} & \multirow{2}{*}{2.5} \\
\hline $\mathbf{1 3 1 0}$ & Za továrňou & Dolná Lehota & Choč dolomites & 2.5 & \multirow{2}{*}{3.3} & \\
\hline $\mathbf{1 3 1 7}$ & Starý mlyn & Dolná Lehota & Choč dolomites & 2.0 & \\
\hline
\end{tabular}

Tab. 2: Groundwater vulnerability of the third hydraulic system - inner groundwater circulation inside the hydrogeological structure.

this hydraulic system, what is typical for rock environment with dense, regular fissure network, with majority of micro-fissures and small fissures. The probability of groundwater contamination is then very small, with the exception of possible entry of contamination from closer vicinity.

\section{CONCLUSIONS}

Final groundwater vulnerability map of research area (Fig. 6), showing a spatial distribution of groundwater sensitivity to pollution - groundwater vulnerability - was based on the reclassification of geological map. Individual lithological types were linked to certain vulnerability degree, depending on the mean value defined from the individual springs recession curves characteristics. The large part of area is highly vulnerable, with vulnerability values of more than 4.9 degree of Kulman's scale (2000) extended by Malík (2005).

This fissure-karst rock environment in the hydrogeological structure on the southern slopes of the Nízke Tatry Mts. between Podbrezová, Krpáčovo, Jasenie and Lopej is widely crushed, with majority of opened, karstic or non karstic fissures and large karst channels. We can assume higher risk of groundwater contamination by surface entry into the rock block here. But in the case of aerial entry of contamination there is still a possibility of its significant retention, absorption and elimination by other processes. Also large part in the centre of structure reaches moderate vulnerability, between $\mathbf{4 . 0}$ and 4.9 degree. In this rock environment we can anticipate the existence of open small fissures in combination with simple, partly phreatic conduit system of considerable extent. Contamination by surface entry is lower, but the possibility of contamination by significant point source with direct connection of the karst system to the surface is real. In the case of aerial entry of contamination, there 


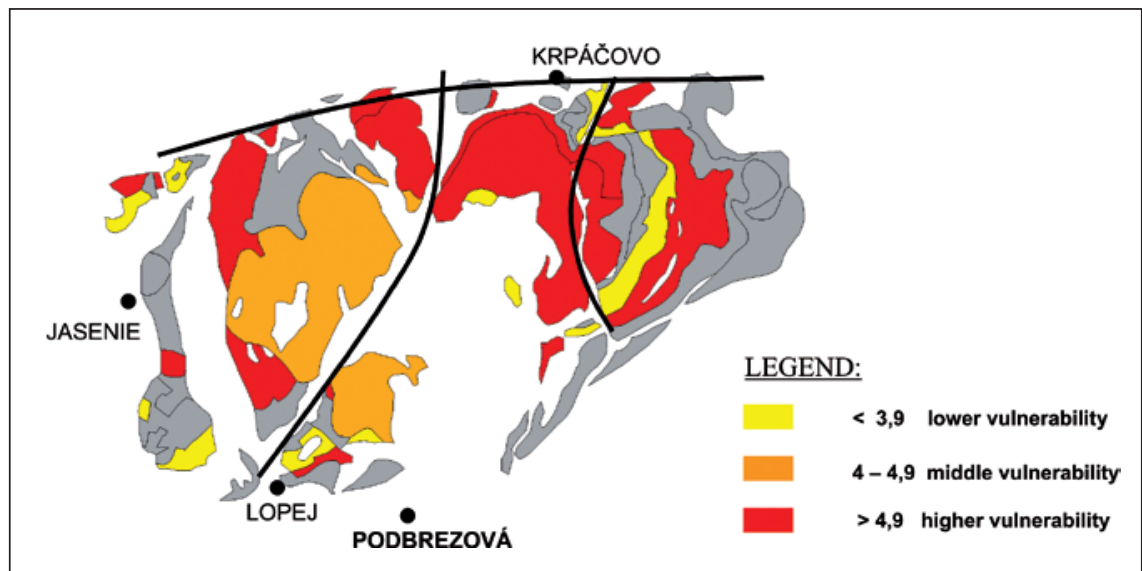

Fig. 6: The outcome map of groundwater vulnerability of research area - hydrogeological structure betwen Podbrezová, Krpáčovo, Jasenie and Lopej, Slovakia. is a possibility of its significant natural attenuation. Only few small parts of hydrogeological structure represent areas with low risk of groundwater contamination, with value of vulnerability degree smaller than 3.9. Rock environment represent a dense network of micro-fissures and small fissures, with only limited extent of karst channels. The risk of more extensive groundwater contamination is very low, with the exception of close vicinity to the pollution source

\section{REFERENCES}

Daly, D., Dassargues, A., Drew, D., Dunne, S., Goldscheider, N., Neale, S., Popescu, Ch., Zwahlen, F. 2002: Main concepts of the „European Approach“ for karst groundwater vulnerability assessment and mapping. Hydrogeology Journal (2002) 10, 340 $-345$

Ibe, K.M. \& Nwankwor, G.I. \& Onyekuru, S. O. 2001: Assessment of ground water vulnerability and its application to the development of protection strategy for the water supply aquifer in Owerri southeastern Nigeria. - Environmental Monitoring and Assessment 67, 323-360, Netherlands.

Kováčová, E. 2005: Zranitelnost' krasovo - puklinových hydrogeologických štruktúr južných svahov Nízkych Tatier. Diploma thesis, p. 117, Faculty of natural sciencies, Comenius University, Bratislava.

Kullman, E. 1983: Režim podzemných vôd s turbulentným prúdením v puklinovo - krasovom horninovom prostredí. - Geologické práce, 79, 237-262, State Geological Institute of Dionyz Stur, Bratislava.

Kullman, E. 1990: Krasovo-puklinové vody. Karst-fissure waters. 184 p., State Geological Institute of Dionyz Stur, Bratislava.

Kullman, E. 2000: Nové metodické prístupy k riešeniu ochrany a ochranných pásiem zdrojov podzemných vôd $\mathrm{v}$ horninových prostrediach s krasovo - puklinovou priepustnostou. - Podzemná voda, VI., 2/2000, 31-41, Slovenská asociácia hydrogeológov Bratislava.
Malík, P. \& Švasta, J. 2004: „Európsky prístup“ hodnotenia zranitelnosti krasových podzemných vôd a možnosti jeho aplikácie v lubovolnom horninovom prostredí. Podzemná voda, X., 1/2004, 50-59, Slovenská asociácia hydrogeológov, Bratislava.

Malík, P. 2005: Assessment of regional karstification degree and groundwater sensitivity to pollution using hydrograph analysis in the Velka Fatra Mts., Slovakia. Water Resources and Environmental Problems in Karst. Proceedings of the International Conference and field seminars Belgrade \& Kotor / Serbia \& Montenegro / 13-19 September 2005, 75 - 80

Hanzel, V., Kullman, E., Dovina, V., Malík, P., \& Vrana, K., 1990: Vysvetlivky ku geologickej mape Nízkych Tatier 1: 50 000. - Čiastová záverečná správa, p. 180, Manuscript - Archive of the State Geological Institute of Dionyz Stur, Bratislava.

Vrba, J., \& Zaporozec, A. 1994: Guidebook on Mapping Groundwater Vulnerability. International contributions to Hydrogeology,16, 39-48, International Association of Hydrogeologist, Hanover.

Zwahlen et al., 2004: Vulnerability and risk mapping for the protection of carbonate (karst) aquifers. - Cost Action 620, p. 297, Office for official publication of the European communities, Luxembourg. 